\title{
An Analysis of the Soccer Passing Technique Skills
}

\author{
Vega Soniawan ${ }^{*}$, Yogi Setiawan ${ }^{2}, \&$ Eval Edmizal $^{3}$
}

\author{
${ }^{1,2,3}$ Dep. of Coaching, Faculty of Sport Science, Universitas Negeri Padang, Padang, Indonesia \\ *Corresponding author. Email: vegasoniawan@fik.unp.ac.id
}

\begin{abstract}
This research is conducted due to the problems found in playing soccer; where some of the players tend to do wrong passing, inaccurate passing, and lack of passing power and quality. The research aims to describe the soccer passing technique skills in using the inside of the foot in terms of movement quality (preparation phase, impact phase, and follow-through) and result quantity of the soccer passing skills. The subjects were 30 soccer players from UPTD West Sumatera Sports Talent. The data collection was conducted through video observation that was assessed by the soccer experts and using the soccer short passing test instrument. Based on the data analysis, it is found that in term of movement quality obtained the average about $12.44(77.78 \%)$ in the preparation phase, $16.18(80.89 \%)$ in the impact phase, and $9.617(80.14 \%)$ in the last phase where those are categorized as sufficient. Meanwhile, in result quantity test obtained the average about $10.13(80.28 \%)$ which was also categorized as sufficient. Thus, the soccer coaches in UPTD West Sumatera Sports Talent can improve the soccer passing technique in term of movement quality and result quantity in each soccer exercise process.
\end{abstract}

Keywords: Skills Analysis, the Soccer Passing Technique

\section{INTRODUCTION}

Many supporting factors influence the athletes to reach the achievements in sports activities; for example, physical conditions, techniques, tactics, and mentality (Soniawan, 2018). Besides, the athletes also must have the good technical mastery to reach their achievements. The achievements sports are kind of sports that foster and develop the athlete in planned, stages, and continued through the competition to reach the achievement which is supported by science and technology.

Playing soccer properly is required to master the soccer technique because it highly supports the athletes. The athletes who have good soccer playing techniques skills might be able to play the ball in various situations. Therefore, it will be easier to play the tactics of playing soccer and also be able to create good teamwork to win in a match.

According to Irfandi (2017), optimal achievements in playing soccer is not only required technical skills but also required a certain number of knowledge about the tactics and winning mentality as well as an excellent physical condition that is possessed by each soccer player. The basic technique, which based on multilateral movement skills, must be mastered by the players to be able to play soccer skilfully. The most important exercise aspects that should be developed by early childhood are the technical skills (the basic movement) and the improvement of physical condition. Therefore, each couch is required to comprehend the stages of exercises to know how many the multilateral and specialization exercises are.

Besides, the soccer players have to master the soccer passing technique due to highly supporting them in playing soccer. The passing technique itself is one of the important techniques that should be mastered by the players. It has its benefit when a player passes the ball to a teammate in close range to arrange the attacks and create goals in a match. Therefore, having a good passing skill drive the players to control the team's game when attacking, and also to have greater opportunity to win.

Al-Hadiqie (2013) stated that mastering passing technique is the players' necessity to perform well as a soccer player. The range of the game is limited if the players do not have good passing skills in a match. Although the passing technique seems simple, it is slightly difficult to do. It can be seen as simple as the professional players do the passing skill in a soccer game. They seem easier playing each other with long and precise passes.

In addition, the passing technique is an individual skill. As stated by Syukur and Soniawan (2015), passing technique is a fundamental technique in soccer to build good teamwork. By having a good passing, the player will be able to run into the open space and control the game as an attack strategy built.

Besides, Emral (2013:76) stated that several aimsof the soccer passing technique; to give the ball to a teammate or to pass the ball, to be an attempt to make a 
goal, and to start over after some fouls (such as free kick, corner kick, penalty kick, goal kick, and so on).Based on those aims, passing the ball is the most important basic technique and widely used in playing soccer. Indeed, good and strong teams are those who master the basic passing technique well, quickly and precisely on targets to the teammates, or the targets in making goals against the opponent. Accordingly, each player has a special foot point where it must be different among the players. Due to its specialty, it allows them to pass the ball accurately and consistently in its direction. (Luxbacher, 2011:11)

Good and effective passing technique is started when a team in its location that controls the ball more. According to Cook (2013) Passing the ball must be given to the right teammate in good controlling range to be able to control the ball and determine the next move. In doing passing movement when having a big chance to pass the ball to a teammate accurately, it needs to do lots of practice and always pay attention to accuracy(Rustanto, 2017).

Additionally, Koger (2007:19) stated that the soccer passing technique can be done in many ways such as in a silent way, moving, floating, or bouncing in the air. Due to the importance of passing technique, it affects the player in playing soccer. In other words, those who cannot be able to do the passing technique are considered not being able to play soccer game. In short, the soccer passing technique is an art to move the ball from a player to another.

Nevertheless, there are many problems found in the field regarding the application of the soccer passing technique. For example, the players often do the wrong passing, inaccurate passing, and lack of passing power and quality. Therefore, the players often have some troubles controlling the ball which makes them miss the ball and it might also allow the opponent to intercept it. It causes the tactics team does not run well in a soccer match. Due to those problems, the researchers analyze to see how the coaches run the exercise program in increasing the soccer passing technique with the inside of the foot. Based on these cases, the researchers do some observations and interviews with some coaches from Soccer School (SSB) who is registered in Padang PSSI City Association, Soccer Academy, and UPTD West Sumatera Sports Talent.

\section{RESEARCH METHODS}

This research aims to describe the soccer passing technique skill in using the inside of the foot in terms of movement quality (preparation phase, impact phase, and follow through). This research was conducted in August 2019. The subjects were 30 soccer players from UPTD West Sumatera Sports Talent. The instrument used was a questionnaire to analyze the soccer passing skills with the inside of the foot by using the soccer passing skills test (Lxbacher, 2011). The data was conducted to analyze the soccer passing skills in movement qualityusing the frequency percentage formula.

\section{RESULTS AND DISCUSSION}

Analysis of Soccer Passing Technique (Movement Quality)

a. Preparation Phase

Based on the results of the analysis on preparation phase of soccer passing technique, the result was obtained as the table below:

Table 1. Frequency Distribution of Preparation Phases of the Soccer Passing Technique

\begin{tabular}{|c|c|c|c|}
\hline \multirow{2}{*}{$\begin{array}{c}\text { Kelas } \\
\text { Interval }\end{array}$} & \multirow{2}{*}{ Kriteria } & \multicolumn{2}{|c|}{ Frekuensi } \\
\hline & & Absolut & Relatif \\
\hline$>13,50$ & Sangat Baik & 2 & 6.67 \\
\hline $12,80-13,50$ & Baik & 8 & 26.67 \\
\hline $12,09-12,79$ & Cukup & 9 & 30 \\
\hline $11,39-12,08$ & Kurang & 9 & 30 \\
\hline$<11,39$ & Sangat Kurang & 2 & 6.67 \\
\hline \multicolumn{2}{|c|}{ Jumlah } & 30 & 100 \\
\hline
\end{tabular}

Based on the table above, 30 samples in this study found 2 people $(6.67 \%)$ in the "very good" category, 8 people $(26.67 \%)$ in the "good" category, 9 people $(30 \%)$ in the "sufficient" category, 9 people $(30 \%)$ are in the "deficient" category, and 2 people $(6.67 \%)$ in the "very deficient".

\section{b. Impact Phase}

Based on the results of the analysis on the in the impact phase of the soccer passing skills the result was obtained as the table below:

Table 2. Frequency Distribution of the Impact Phases of the Soccer Passing Technique

Based on the table above, 30 samples in this study found that 1 person $(3.33 \%)$ in the "very good" category, 7

\begin{tabular}{|c|c|c|c|}
\hline \multirow{2}{*}{$\begin{array}{c}\text { Kelas } \\
\text { Interval }\end{array}$} & \multirow{2}{*}{ Kriteria } & \multicolumn{2}{|c|}{ Frekuensi } \\
\hline & & Absolut & Relatif \\
\hline$>1790$ & Sangat Baik & 1 & 3.33 \\
\hline $16,75-17,90$ & Baik & 7 & 23.33 \\
\hline $15,60-16,74$ & Cukup & 13 & 43.33 \\
\hline $14,46-15,59$ & Kurang & 7 & 23.33 \\
\hline$<14,46$ & Sangat Kurang & 2 & 6.67 \\
\hline \multicolumn{2}{|c|}{ Jumlah } & 30 & 100 \\
\hline
\end{tabular}

people $(23.33 \%)$ in the "good" category, 13 people 
$(43.33 \%)$ in the "sufficient" category, 7 people $(23.33 \%)$ in the "deficient" category, and 2 people $(6.67 \%)$ in the "very deficient" category.

c. Final Phase (Follow Through)

Based on the results of the analysis on the last phase (follow through) of soccer passing technique, the result was obtained as the table below:

Table 3. Frequency Distribution of Final Phases of the Soccer Passing Technique

\begin{tabular}{|c|c|c|c|}
\hline \multirow{2}{*}{$\begin{array}{c}\text { Kelas } \\
\text { Interval }\end{array}$} & \multirow{2}{*}{ Kriteria } & \multicolumn{2}{|c|}{ Frekwensi } \\
\hline & & Absolut & Relatif \\
\hline$>10,73$ & Sangat Baik & 1 & 3.33 \\
\hline $9,99-10,73$ & Baik & 11 & 36.67 \\
\hline $9,25-9,98$ & Cukup & 10 & 33.33 \\
\hline $8,50-9,24$ & Kurang & 5 & 16.67 \\
\hline$<8,50$ & Sangat Kurang & 3 & 10.00 \\
\hline \multicolumn{2}{|c|}{ Jumlah } & 30 & 100 \\
\hline
\end{tabular}

Based on the above, 30 samples in this study found 1 person $(3.33 \%)$ in the "very good" category, 11 people $(36.67 \%)$ in the "good" category, 10 people $(33.33 \%)$ in the "sufficient" category, 5 people $(16.67 \%)$ were in the "deficient" category, and 3 people $(10.00 \%)$ in the "very deficient" category.

Achieving the level of team success in soccer games depends on the team's cooperation in improving the passing techniques along with the other technical skills. These technical skills complete each other because passing is one technique to produce a goal.

Furthermore, the success of each attack depends on each player's technique for controlling the ball. The opponent's attack and the skills to deal with one or more opponents who try to intercept the ball is the crucial thing for individual success. As a result, the players can use various parts of the hand to give a direction to pass the ball in reaching the main target.

Each soccer player should master the soccer techniques because it highly supports them in a game. The passing technique itself is the most crucial skill should be owned and mastered by the soccer players. By mastering this skill, they can pass the ball to a closerange teammate to arrange the attacks and create a goal in a game. The more the players have a better passing technique, the more they have the opportunity to control the game when attacking the opponents and winning the match.

Moreover, the success of each attack depends on each player's skills to control the ball. The defeat skills in passing will appear in one-on-one situations, especially in the opponent's attack area. Besides, the ability in facing the opponent who tries to intercept the ball is also a crucial thing for individual success. The players can use various parts of the foot (inside and outside) to control the ball when dribbling it. It aims to reach the main target passing the opponent while controlling the ball. If the player succeeds to pass the opponent, he/she may have a chance to create a goal.

The techniques quality- such as anticipation, stability, and calmness under the opponent pressure- is equally important. The players may reach the main target more often than they expected because to create a goal is the most difficult thing in playing soccer. To create a goal, the players should be able to do the well passing technique under the opponent pressure in a time limit, physically tired, and the aggressive opponents.

In other words, the passing technique skills possessed by the players of UPTD West Sumatera Sports Talent is quite good already. It can be seen from the implementation of the passing technique with the inside of the foot that have correctly done in the three phases; the preparation phase, the impact phase, the final phase (follow-through). However, after looking at the players' achievement data of UPTD West Sumatera Sports Talent in the past year, it showed that they were not able to perform well because it was influenced by several other achievement component factors, namely physical, tactic and mental conditions.

\section{CONCLUSIONS AND SUGGESTIONS}

\section{A. Conclusions}

Based on the research results, it can be concluded that the stage of the soccer passing technique analysis with the inside foot in term of movement quality obtained the average about $12.44(77.78 \%)$ in the preparation phase, $16.18(80.89 \%)$ in the impact phase, and $9.617(80.14 \%)$ in the last phase (follow-through) where those are categorized as sufficient. Meanwhile, in result quantity test obtained the average about 10.13 $(80.28 \%)$ which was also categorized as sufficient. Thus, the soccer coaches in UPTD West Sumatera Sports Talent can improve the soccer passing technique in terms of movement quality and result quantity in each soccer exercise process.

\section{REFERENCES}

[1] Al-Hadiqie, Zidane Muhdhor. (2013). Menjadi Pemain Sepakbola Profesional. Jakarta: Kata Pena.

[2] Cook,Malcolm. (2013). 101 Drills Sepakbola Untuk Pemain Muda Usia 12-16 Tahun. Jakarta: PT. Indeks.

[3] Emral. 2013. Pengembangan Model Latihan Keterampilan Teknik Dasar Bermain SepakbolaSiswa SSB PSTS Padang. Jakarta: PPs. UNJ.

[4] Irfandi, I., \& Rahmat, Z. (2017). Pengembangan Model Latihan Keterampilan Teknik Menggiring Slalom Dan Mengoper Dalam Sepakbola. 
Penjaskesrek Journal, 4(2).

[5] Koger,Robert. (2007). Latihan Dasar Andal Sepakbola Remaja. Klaten: PT Saka Mitra Kompetensi.

[6] Luxbacher, Joseph A. 2011.Sepakbola Edisi Kedua. Jakarta: PT. Raja Grafindo Persada.

[7] Mielke,Danny. (2007). Dasar-Dasar Sepakbola. Bandung: Pakar Raya.

[8] Rustanto, H. (2017). Upaya Meningkatan Keterampilan Passing Sepakbola Dengan Kaki Bagian Dalam Menggunakan Metode Bermain. Jurnal Pendidikan Olahraga, 6(1), 21-32.

[9] Setiawan, Y., Sodikoen, I., \&Syahara, S. (2018). Kontribusi Kekuatan Otot Tungkai terhadap Kemampuan Dollyo Chagi Atlet Putera Tae Kwon Do di BTTC Kabupaten Rokan Hulu. Performa Olahraga, 3(01), 15-15.

[10] Soniawan, V. Metode Bermain Berpengaruh Terhadap Kemampuan Long Passing Sepakbola.

[11] Syukur, A., \& Soniawan, V. (2015). The Effects Of Training Methods And Achievement Motivation Toward Of Soccer Passing Skills. Jipes-Journal Of Indonesian Physical Education And Sport, 1(2), 7384.

[12] Tarju, T., \&Wahidi, R. (2017). Pengaruh Metode Latihan Terhadap Peningkatan Passing Dalam Permainan Sepak Bola. JUARA: Jurnal Olahraga, 2(2), 66-72. 